\title{
Homily of His Eminence Archbishop Józef Kowalczyk,
}

\author{
Archbishop of Gniezno and Primate of Poland delivered during Holy \\ Mass celebrated at the Holy Spirit Church in Rome on the occasion of \\ the 30th anniversary of the establishment of the Vatican's John Paul II \\ Foundation Rome, October 23, 2011
}

\section{Blessed be God in His Blessed and in His saints!}

With these words, I welcome and greet all of you who gathered today in the Church of the Holy Spirit in Rome, in thanksgiving prayer for the 30 years of existence and activities of the Vatican's John Paul II Foundation, which Blessed John Paul established by Himself.

The Thanksgiving Eucharist is celebrated in the beautiful church situated so close to St. Peter's Basilica where the relics of Blessed John Paul II are located.

We arrived here on a pilgrimage and as pilgrims.

Some may ask: what is a pilgrimage?

A pilgrimage is a journey of a single person or an organized group to a place of worship, in order to celebrate somebody or something; it is a journey to a sacred place, taken for religious reasons, in order to pay homage to that place or relics that are located there, to give thanks, to ask for graces or to fulfill an act of penance.

John Paul II said once that "pilgrimages are like milestones indicating the path to God's children who are wandering through the earth" (cf. Homily in Corrientes, Argentina, September 4, 1997).

What is a pilgrim?

A pilgrim is a particular person, who alone or in organized groups, undertakes the journey for a specific purpose which he or she intends to achieve. 
My Dear Brothers and Sisters!

In the country of Blessed Pope John Paul II, in which he grew in his humanity; in his human, priestly and bishop vocation, walking pilgrimages to various sanctuaries are well known and practiced. Especially well known during the month of August is a pilgrimage to Jasna Góra shrine where the miraculous image of the Queen of Poland is located. This annual August pilgrimage is a great gift of grace and sometimes they are called "retreats on the road", as they help a man to get closer to God through Mary, as our Mediatrix of all graces.

In this context, we should repeat the words of the responsive Psalm from today's 30th Ordinary Sunday:

"Long live the Lord, blessed be my rock.

Exalted be my God and Savior!” (Ps.18/17,47)

My Dear Brothers and Sisters!

On October 28, 1998, we gathered in this Rome's Church of the Holy Spirit to gave thanks for the 20 years of fruitful evangelistic ministry of then Pope John Paul II. At this time I would like to recall the words I said at that time:

"Representatives of the John Paul II Foundation Chapters from around the world, concerned about the spiritual heritage of faith, love, and hope associated with the apostolic mission of the Pope, gathered today in the church of the Holy Spirit in Rome to make a thanksgiving Eucharistic offering for the twenty years of Eucharistic Pontificate of John Paul II in the Church and forty years of His Episcopal ministry”.

"I'm glad that in the year of the Holy Spirit you experienced so many inspirations to do good deeds that your names have been placed on the memorial plaques at the Polish Home on Via Cassia 1200".

"The Holy Father establishing His Vatican's Foundation clearly referred to another type of pilgrimage - pilgrimages of cultures; pilgrimages of the Christian culture from Rome to various regions of Europe and the world and vice versa, the pilgrimages of many cultures (including Polish culture) to the centre of Christianity, that is Rome".

In this statement, we can see a resemblance to the theological reflections, particular National churches, present in the Catholic Church and the Catholic Church present in particular National churches.

Somebody may ask: What is culture?

An answer to this question was provided by John Paul II in His speech to young people gathered at the Lech Hill in Gniezno, Poland:

"Culture is an expression of man, It is a confirmation of humanity. Man creates culture and by means of culture creates himself. He creates himself with the 
inward effort of the spirit, of thought, will and heart. At the same time he creates culture in communion with others. Culture is an expression of communication, of shared thought and collaboration by human beings. It is born of service of the common good and becomes an essential good of human communities".

Culture is above all a common good of the nation. Polish culture is a good on which the spiritual life of Poles rests. It distinguishes us as a nation. It is decisive for us throughout the course of history, more decisive even than material power. Indeed, it is more decisive than political boundaries. The Polish nation, as is well known, passed through the hard trial of the loss of its independence for over a hundred years and in the midst of this trial it preserved its own identity. It remained spiritually independent because it had its own culture. Indeed, in the period of the partitions, it still greatly enriched its culture and made it deeper, since it is only by creating culture that it can keep itself in being.

From its beginnings, Polish culture bears very clear Christian signs. It is no coincidence that the origin of this culture starts with Bogurodzica. It is still so today; Christian inspiration continues to be the chief source of the creativity of Polish artists. Polish culture still flows with a broad stream of inspirations that have their source in the Gospel.

In the works of Polish culture the soul of the nation is reflected. In them lives the nation's history, a history that is a continual school of solid sincere patriotism. For this reason, that same history can make demands and uphold ideals without which it is difficult for man to believe in his own dignity and educate himself.

My Dear Friends,

You are hearing these words from a man who owes his own spiritual formation from the beginning to Polish culture, to its literature, its music, its arts, its theatre - to Polish history, to the Polish Christian traditions, to the Polish schools, the Polish universities...At the same time, this man wishes to appear before you today with this heritage which is the common good of all Poles and constitutes an outstanding part of European and world culture.

And I ask you:

Remain faithful to this heritage. Make it the foundation of your formation. Be nobly proud of it. Keep this heritage and multiply it; hand it on to future generations.

(Gniezno, June 3, 1979)

My Dear Brothers and Sisters!

The words of this Great Pilgrim, now Blessed John Paul II, who for many years participated in the pilgrimages to the centre of Christianity and later as the 
Pilgrim Pope from the Christian centre. He made pilgrimages to so many nations around the world including His own country. He brought with him his Christian culture as Universal Pastor of the Universal Church. Hence, in reality mutual pilgrimages of cultures and mutual cultures and spiritual enrichment exist. John Paul II confided sometimes that when He makes pilgrimage to a country or a particular church at some continent, He was coming there as a teacher and as a student. As the head of the Catholic Church he made pilgrimages to proclaim His unshakable Faith and Christian culture. As a student, He made pilgrimages to learn, to show respect and to appreciate local traditions that were a part of a specific culture, a nation, or a particular church, and doing it He was enriching the culture of the Universal Catholic Church.

In this parallel pilgrimage we can find an echo of the words from the second reading of today's Liturgy of the Word:

"And so you became a model to all the believers... The Lord's message rang out from you...” (1 Tes. 1, 7-8)

My Dear Friends!

Please accept my words of respect and recognition, that for the 30 years you remained faithful to this pilgrimage to Rome that involves you and your culture. By your work you graciously support the main goals of the John Paul II Foundation - dissemination of now Blessed John Paul teachings.

Our Father reminded us that man is the way of the church, and that the crowning work of creation is every single human being who has inalienable rights and inviolable dignity. He was reawakening our conscience on the values of a human life; He was a great advocate of harmony and peace among all nations, which can be reached by a dialogue and not by armed conflicts. He was a spokesman and a defender of the underdeveloped communities and nations.

The entire world read and understood John Paul II's fatherly and brotherly concern for dignity of the human person. This was manifested during his funeral and at the day of His beatification that took place on May 1st of this year.

Gathered today in this church, we would like to offer at the altar of the Eucharist, our thanksgiving for God's great gift to the Church and all humanity that was Blessed John Paul II.

We would like to express our gratitude through the intercession of Our Lady of the Rosary, who we especially venerate in October.

Blessed John Paul II had a great devotion to Our Lady of the Rosary. He recited the Rosary daily. It was He who introduced the Luminous Mysteries as the fourth part of the Rosary (October 16, 2002). In the Apostolic Letter Rosarium 
Virginis Mariae (the Rosary) directed to us, as God's people, He was asking and encouraging us to rediscover the power of the Rosary prayer.

John Paul II said: “At the same time, our heart can embrace in the decades of the Rosary, all the events that make up the lives of individuals, families, nations, the Church, and all mankind.” We can introduce our personal matters, concerns for our loved ones as well as all the activities of the John Paul II Foundation. We now pray for all members and friends of the Foundation, for all those who are taking care of the Foundation and its future.

My Dear Brothers and Sisters!

I wish to end our meditations and thanksgiving with a prayer:

Blessed John Paul II, who established this Foundation and set up its goals and are looking at us from the Heavenly Father's House, we ask You to continue to support us through Your intercession, we kindly ask for a gift of wisdom and persistence that we could, with a great devotion, realize all of the Foundation's goals. Let dissemination of your teachings and testimony of your holy life enrich us and all the cultures of the nations and countries. Amen. 